UDC 339.9:659.1.012.12

DOI: https://doi.org/10.32782/2413-9971/2021-35-14

Tsviliy Sergiy

Candidate of Economic Sciences, Associate Professor, Senior Lecturer at Department of Tourism, Hotel and Restaurant Business «Zaporizhzhia Polytechnic» National University

Gurova Darya

Candidate of Geographical Sciences, Associate Professor, Senior Lecturer at Department of Tourism, Hotel and Restaurant Business «Zaporizhzhia Polytechnic» National University

Zhuravlova Svitlana

Candidate of Economic Sciences,

Senior Lecturer at Department of Tourism, Hotel and Restaurant Business «Zaporizhzhia Polytechnic» National University

Цвілий С. М. кандидат економічних наук, дочент, дочент кафедри туристичного, готельного та ресторанного бізнесу Начіонального університету «Запорізька політехніка»

Гурова Д. Д. кандидат географічних наук, доцент, доиент кафедри туристичного, готельного та ресторанного бізнесу Національного університету «Запорізька політехніка»

Журавльова С. М. кандидат економічних наук, доцент кафедри туристичного, готельного та ресторанного бізнесу Національного університету «Запорізька політехніка»

\title{
MARKETING OF THE DOMESTIC HOTEL AND RESTAURANT ENTERPRISE IN THE INTERNATIONAL DIGITAL SPACE
}

Summary. The article considers theoretical approaches to the development of digital services. The world experience in studying methodical tools in the field of service marketing is generalized. A model of a complex hotel and restaurant product has been developed. Practical recommendations for the implementation of digital marketing strategy for hotel and restaurant services are provided. The scheme of organizational construction of the marketing department of the hotel and restaurant company in accordance with the requirements of digitalization of business is offered. The priority tasks of the domestic hotel and restaurant enterprise in the formation of consumer thinking of digital consumption are defined. It is concluded that further explorations are interesting in terms of developing a mechanism for studying the digital loyalty of customers of a complex hotel and restaurant product.

Key words: marketing, digital space, international business, hotel and restaurant business, strategy, consumer.

Introduction and problem statement. Today, among the basic factors for successfully overcoming the effects of the global economic and tourism crisis caused by COVID-19, scientists highlight the complex, multifaceted nature of the impact of integration in the field of international tourism on the entire regional development of hotel and restaurant business in Ukraine. It is this specific feature that arises from the special crucial role of digital services in the coronavirus and post-coronavirus eras. In direct connection with this feature there is such a peculiarity of digitalization in this area as the need for prevention. Unlike previous periods of international cooperation, when the internationalization of world tourism followed the internationalization of the economy, in modern conditions, digital service acts as a crucial resource, and the process of providing acquires the status of continuity, cooperation in digital service should be ahead of development of this process in other areas within international tourism. The transformation of global business and social institutions to new economic conditions dictates the trajectory of development of the domestic tourism industry, which in recent years has rapidly increased levels of diversification and openness to the world community and international cooperation. Given the special status of the service economy in the coronavirus period, the hotel and restaurant subsystem of global tourism strengthens its position as one of the crucial elements of high world politics. Under the influence of permanent international systemic causes of instability, evolution of value vectors of countries, political and economic changes, ecological and spatial changes, against the background of global security challenges to humanity, the domestic hotel and restaurant business is becoming international.

It is known that the development of digital services is formed within the concept of digital service economy. Digital services are the foundation of this type of new economy; they contribute to the development of virtual market infrastructure, digitalization and social orientation of the economy, improving the quality of digital life in society. Today in the EU countries the share of digital services in the total volume of services exceeds $80 \%$ and this state of the service economy indicates the digital orientation of enterprises and is based on marketing and IT efforts of business structures in the service sector [1]. That is why the study of the development of digital services is relevant for domestic scientists.

Analysis of recent research and publications. Consideration of various expert opinions allows us to understand that analysts deliberately identify several reasons for the progressive 
development of the digital services market in microbusiness: the loss of the vast majority of economic subsystems of dynamism in the global coronavirus economic crisis; the material component in the production of services is becoming an increasingly inefficient unit that satisfies the basic interest of the consumer; rapid growth of unemployment, which has a negative impact on the structure of economic resources and social tensions; crisis of production of services; health problems in the regions.

Fundamental studies of the essence of international business are revealed in the works of prominent Ukrainian and foreign scientists, in particular: K. Aswazappa, D. Johnson, O. Mikhailovska, S. Mochernyi, S. Paulson, K. Simmonds, B. Toyne, S. Fomyshyn and others. Many publications are devoted to the process of improving theoretical models of service marketing, the authors of which are such scientists as L. Berry, A. Parasuraman, D. Ratmel, L. Eiglie, E. Langeard, V. Zeithaml, M. Bitner, P. Kotler, E. Hammeson, Ch. Grönroos and many others. Considerable attention to marketing in the field of tourism and hotel and restaurant business is paid in the scientific studies of A. Vindiuk, S. Hres-Yevreinova, A. Durovych, V. Zaitseva, O. Kornienko, V. Kyfiak, T. Kuklina, L. Strashynska and others researchers [2-8]. However, recognizing the significant achievements of many scientists, it should be noted that there have not been studied some problematic aspects of the study of the specifics of the marketing of the hotel and restaurant company and the product in terms of COVID-19 yet. In particular, when recognizing the need for digitalization of the hotel and restaurant business, the issues of finding ways to attract and retain customers based on the offer of digital products are unresolved. This confirms the timeliness of the chosen topic of work in the face of the negative factors of the coronavirus economy.

The purpose of this article is to study the conditions of development of digital services based on justification of the model of complex hotel and restaurant product development of practical recommendations for the formation and implementation of digital marketing strategy of domestic enterprises in the international virtual space.

Results of the research. Generalization of world experience in the study of methodological tools in the field of service marketing has concluded that the vast majority of typical models are based on a clear definition of the type of service and, consequently, depending on the type of service, there is a need for appropriate marketing activities. The approach to the division of services into types is important for marketing because it affects such characteristics of the service as flexibility of quality, the possibility of simultaneous production and consumption of the service, the separation of the service from the contractor, the ability to store the service. Most typical models are based on the distribution of services according to two criteria: first, the form of satisfaction of needs, according to this, services are located on a scale: from "pure service" to service related to the product; second, the tool or method of meeting the need: personnel or mechanisms, according to which the services are located on a scale - from those where the service is provided by employees of the service company, and ending with those where the consumer receives the service through an automatic device or mechanism.

In general, this approach in service marketing complements the classical theories, which are based on finding common ground in different services, and the division of services into types according to the criteria "form of satisfaction" and "tool or method of satisfaction" may be different [9]. On the one hand, the service may consist only in a qualitative or quantitative change in the consumer's assets, on the other hand, to implement a certain type of hotel and restaurant services, the consumer must purchase material goods. In the first case, the customer receives benefits only through the actions taken by the service provider, in the second, through the actions and delivery of the material product. According to this criterion, hotel and restaurant services range from "pure service" to "product service" [10]. As the boundaries of the service are quite flexible, one of the tasks of marketing hotels and restaurants is to find out consumer preferences and create a product portfolio in a form that will be better perceived by customers. Using this approach allows you to change the view of the company's positioning, work with the company's product portfolio, identify areas of strategic development, marketing strategy development and, ultimately, the choice of marketing tools to form supporters of the company.

However, the transition of the global tourism economy to the post-coronavirus era is accompanied by the emergence of marketing management problems, which are extremely complex in content; their solution must be found by combining the efforts of leading scientific schools and using the potential of economic tourism systems of both national and international format $[11 ; 12]$. It should be assumed that the creation of a new paradigm of the service economy of tourism is becoming an additional factor in its internationalization. The search for a vision of development during and after the COVID-19 pandemic is gradually transforming the global tourism and hotel and restaurant industry into an international laboratory for developing optimal steps towards a systematic vision of marketing strategy taking into account the interests of companies.

Today, the international business is experiencing a digital revolution: almost all people use computer technology, the main engine of change is the customer; the needs dictate the conditions in the digital market of hotel and restaurant services. The strategic success of companies in the fight against competitors depends on the introduction of digital marketing, understanding of the technologies of which allows ensuring the internationalization of the hotel and restaurant business and fully entering the global digital space with their own product. That is why the authors offer a model of a complex hotel and restaurant product in Figure 1.

To build the proposed model, a dual criterion was used: a complex hotel and restaurant product (hotel and restaurant) and its presentation in space (real and digital). According to the specified scheme in Figure 1, each service falls into one of the four quadrants (AC, $\mathrm{AD}, \mathrm{BD}, \mathrm{BC})$. In turn, the hotel and restaurant company has four vectors of development of a complex hotel and restaurant product: $(\mathrm{O} \rightarrow \mathrm{AC}, \mathrm{O} \rightarrow \mathrm{AD}$, $\mathrm{O} \rightarrow \mathrm{BD}, \mathrm{O} \rightarrow \mathrm{BC}$ ). It should be added that some hotel and restaurant services, which are located near the axes of the coordinate system (OA and $\mathrm{OB})$, have almost the same undeveloped representations in real and digital space.

Undoubtedly, the implementation of this model in the business practice of the domestic hotel and restaurant companies is at a strategic level. From this point of view, the following practical recommendations for the formation and implementation of a digital marketing strategy for hotel and restaurant services are appropriate.

Firstly, taking into account the modern concept of service organization, from the standpoint of which, in the long run, the hotel and restaurant company is trying to survive in terms of management short- and medium-term safety through coordinated behavior with consumers in the digital space.

Secondly, the choice of methods of digital change in marketing strategy based on the cycle of digital competitive advantage of the firm, which includes typical stages: the emergence, acceleration, deceleration, maturity, and decline. It is clear that at each stage the state of digital competitiveness will be different and therefore, in accordance with the strategy, changes in factors should be monitored. 
Complex hotel product (hotel services package)

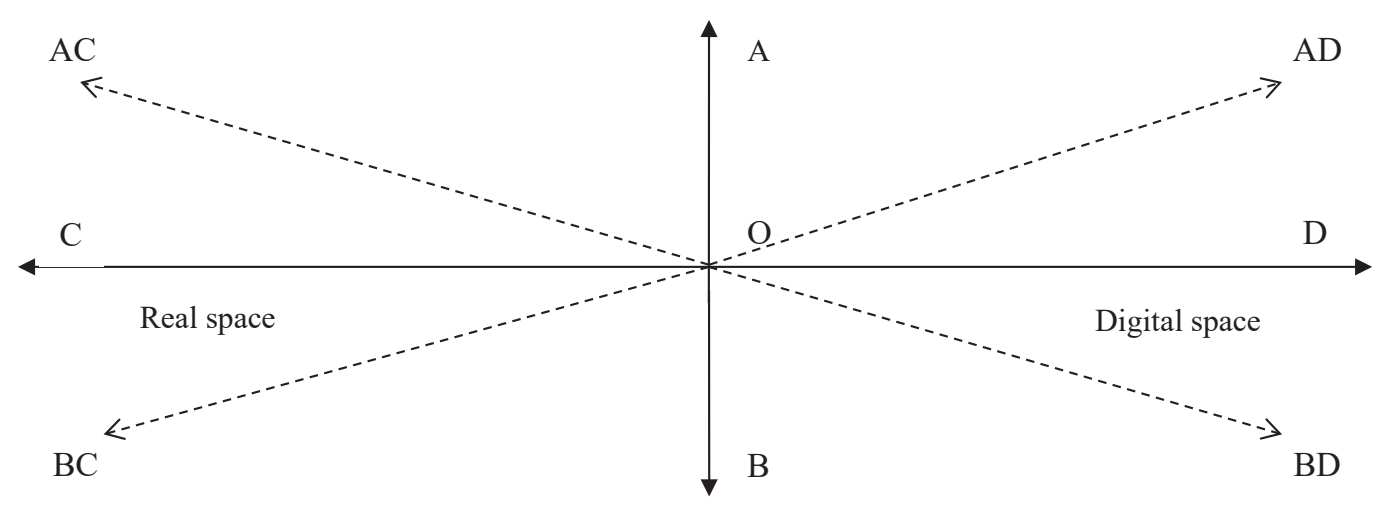

Complex restaurant product (package of restaurant services)

Figure 1. Model of complex hotel and restaurant product:

\author{
$\mathrm{OA}$ - range of hotel services of the enterprise; \\ $\mathrm{OB}$ - range of hotel services of the enterprise; \\ $\mathrm{OC}$ - presentation of a complex product in real space; \\ $\mathrm{OD}$ - presentation of a complex product in digital space.
}

Thirdly, the identical presentation of the hotel and restaurant product in real and digital space at a level that provides the customer with an understanding of the possibility of meeting future requirements, as well as confidence that the digital product will always have an integrated correspondence to the real.

Fourthly, the strategic competitiveness of services should be considered in a two-dimensional aspect, i.e. it is advisable to take into account the real and digital interests of consumers (consumer qualities of the product) and sellers (profit level).

Fifthly, timely recording of changes in business conditions and the implementation of appropriate changes in the digital policy of product sales: certain changes in product policy, introduction of new technologies, diversification, changes in organizational and legal status, modernization of forms and sales channels.

Sixthly, the use of digital marketing tools in the management of the firm, which accelerates the transformation of the economic subsystem, helping to control changes in supply and demand, and helps to promote the basic ideas of digital transformation, promoting consumer perception.

Seventhly, the impact on the consumer through a system of levers, which are elements of the hotel and restaurant marketing.

Eighthly, the implementation of the provisions of marketing management of the level of digitalization of business on the principles of: flexibility and adaptation to constant changes in a changing environment; perception of the company as a digital system; situational approach; transformation of the system of strategic management of the level of digitalization of hotel and restaurant product; development of the company's internal system of digital parameters and standards; formation, digital control and recognition of digital responsibility to customers and partners of the enterprise.

Ninthly, forecasting long-, medium- and short-term goals of digital marketing based on a combination of resources and digital technologies for their rational use in the management of a hotel and restaurant company.

Tenthly, the creation of digital management structures to ensure the implementation of strategic, tactical, operational marketing goals, integration of departments and specialists involved in the process of production and sale of the product, as well as coordination of their activities in real and digital space.

To overcome obstacles to the implementation of digital marketing strategy, the domestic hotel and restaurant company should completely reform the organizational structure of marketing and separate the units responsible for digitalization of business in general and digital marketing in particular. In the post-coronavirus environment, only those hotel and restaurant companies, in which management and staff have the desire and aspiration to develop in the international digital space, will be able to secure a stable position in the market. In accordance with the requirements of business digitalization, the following scheme of organizational construction of the marketing department of a hotel and restaurant company is proposed, namely: creation of a digital technology department, which will include work on structuring and organizing marketing information into a synchronized digital system, integration of this system with CIS Internet marketing department, whose tasks should include measures to attract additional customers through Internet resources (Figure 2).

Unfortunately, there is little practice of digitalization results in the domestic digital space, and that is why this process tends to systematize. The technology of transformation to a digital hotel and restaurant company should consist of the following three parts: first, the overall marketing strategy; second, the digitization of tactical marketing; and third, the automation of marketing operations. Under such conditions, one of the options for marketing, taking into account the latest trends, both science and practice, is the digital type of marketing of international databases and the transition from selective segmentation of consumers to individual marketing in the digital space.

In general, the use of digital technologies in conjunction with innovative approaches to managing real and digital customer relationships in a modern hotel and restaurant business will increase the profitability of sales of integrated products, services, greater customer satisfaction, save time and labor costs as a result of automation and optimization of operations, as well as activating the creative potential of marketing staff. As a result of the negative impact of the global crisis due 


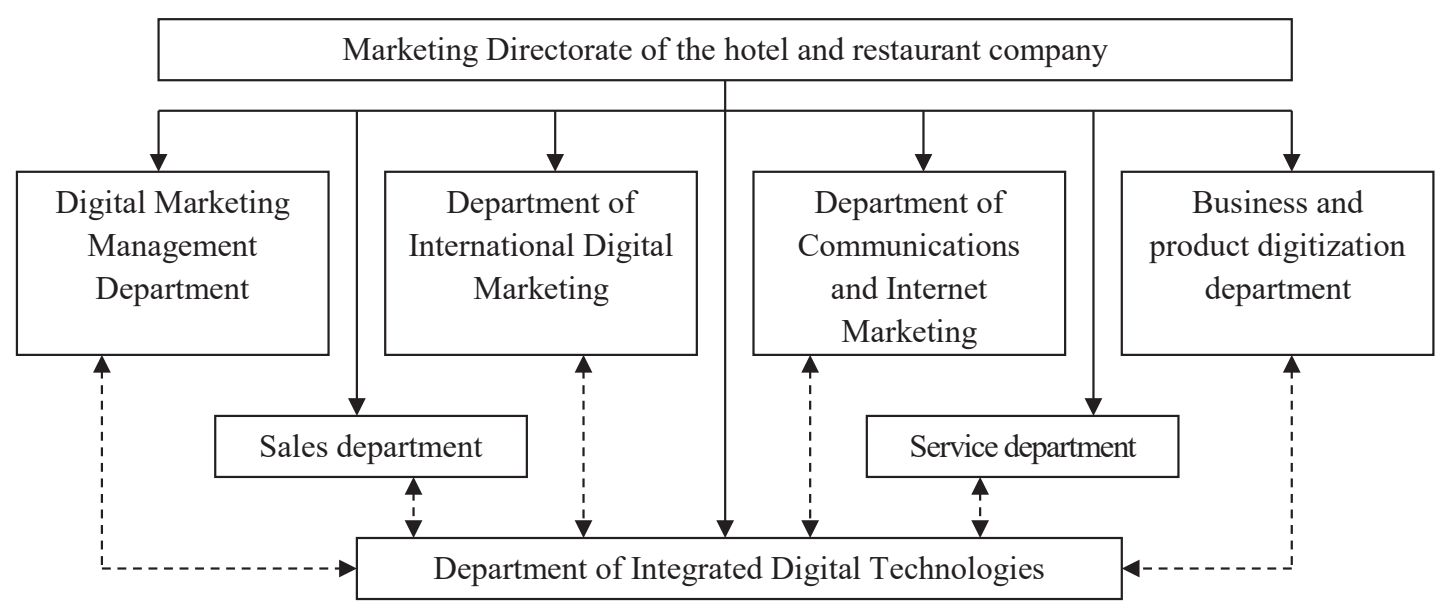

Figure 2. Organizational structure of the marketing department of the hotel and restaurant company

to the COVID-19 pandemic, increasing flows of marketing information, reorientation of consumption, radical changes in the digital level of business, technology transfer, the basic conditions for effective marketing in hotel and restaurant are: rational organizational structure of marketing, staff with relevant competencies and interest in the results of work, digital support of marketing decisions.

In this regard, in order to establish rational interaction in the digital international space of hotel and restaurant companies with buyers of complex products, the following requirements to the marketer are identified: implementation of digital policy of the firm by satisfying business interests (1); solving extreme problems by making marketing decisions given the situation in the digital environment (2); virtual time management through rational delegation of authority (3); identification and recruitment of high-quality IT specialists to the marketing department by prioritizing experience (4); checking the "digital marketing suitability" of professionals by monitoring behavior in problem situations (5); expanding and deepening the competence of IT marketers by increasing the level of complexity of digital tasks, appropriate support (6); strategic thinking and creating a mechanism for achieving goals through effective goal setting and digital control of their implementation (7); installation of information "filters" by creating a contactless secretary and the elimination of unnecessary "service" functions in the digital information exchange with customers (8); support of external relations by establishing profitable virtual relations from mutual relations with partners from the microenvironment of the hotel and restaurant enterprise (9); avoidance of conflicts in the team by creating a hierarchical digital structure with certain established priorities of specific persons and positions of the enterprise (10).

The priority tasks of the domestic hotel and restaurant company in the formation of consumer thinking of digital consumption are: increasing the level of consumer competence (1); organization of a holistic marketing system for digital client education (2); formation of the ability to make a free, con- scious choice of a complex hotel and restaurant product and use all the services of the institution (3); promoting clients' access to reliable information on the rational choice of services (4); development of norms of tolerant behavior and loyalty, motivation for correct timely feedback, desire to resolve conflicts (5); development of digital consumer erudition (6); formation of the ability to coordinate their own actions with the business interests of the domestic hotel and restaurant company in the international digital space (7).

Conclusions. In general, digital technologies are ineffectively changing consumer behavior and formulate the latest challenges for the marketing system of hotels and restaurants. Marketing insights of companies must reflect the adequate digital environment of today: in preparation for the unforeseen challenges of the post-coronavirus economy to succeed, domestic enterprises should respond effectively to the opportunities of the international digital space arising from global digitalization, the emergence of new types of data innovative technologies. The main direction of safe operation of the newest Ukrainian hotel and restaurant business in the post-coronavirus digital space and the condition of its successful integration into the international digital system can be a strategic vision of the global digital marketing concept, the main idea of which is to form typical hotel and restaurant companies in different countries according to uniform principles, rules and laws. Currently, there are few problems that would be more important than the one associated with finding ways to organize an effective hotel and restaurant digital business in harmony with the constant crisis of a rapidly changing world. Today, there is a real opportunity to determine the digital path of the domestic enterprise on the basis of a combination of international experience, the ability to adequately present the hotel and restaurant product in the digital space, creating a single virtual global environment, new needs and consumer segments. Prospects for further exploration in this direction should be interesting in terms of developing a mechanism for studying digital consumer loyalty.

\section{Список використаних джерел:}

1. Індустрія гостинності в Україні: стан і тенденції розвитку : Колективна монографія. Колектив авторів / за заг. ред. В.М. Зайцевої. Запоріжжя : Просвіта, 2017. 240 с.

2. Михайловська О.В. Вплив глобалізації інформаційного простору на розвиток міжнародних інноваційно-інвестиційних процесів : монографія / О.В. Михайловська. Київ : Дакор : Скіф, 2009. 424 с.

3. Мочерний С.В. Інтернаціоналізація виробництва і сучасні тенденції розвитку світового господарства / С.В. Мочерний. Економіка України. 2006. № 5. С. 47-55.

4. Фомишин С.В. Междунароные экономические отношения на рубеже тысячелетий : учеб. пособ. / С. Фомишин. Херсон : Олди-плюс, 2002. 560 c. 
5. Котлер Ф. Маркетинг в третьем тысячелетии: как создать, завоевать и удержать рынок / пер. с англ. В.А. Гольдича [и др.]. Москва : Издательство «АСТ», 2000. 272 с.

6. Кифяк В.Ф. Стратегія розвитку територіальних рекреаційних систем: теорія, методологія, практика : монографія. Київ; Чернівці : Книги-XXI, 2010.

7. Страшинська Л.В. Маркетинг готельного і ресторанного господарства / Л.В. Страшинська. Київ : НУХТ, 2011.89 с.

8. Дурович А.П. Маркетинг в туризме : учебное псобие / А.П. Дурович. Минск : Новое знание, 2003. 496 с.

9. Стратегічне управління готельними підприємствами в умовах глобалізації : Колективна монографія. Колектив авторів / за заг. ред. В.М. Зайцевої. Запоріжжя : ЗНТУ, 2018. 120 с.

10. Кукліна Т.С., Корнієнко О.М Міжнародний готельний бізнес: проблеми та перспективи. Інфраструктура ринку. 2019. № 31. Режим доступу: http://www.market-infr.od.ua/journals/2019/31_2019_ukr/6.pdf

11. Tsviliy S., Gurova D., Bulatov S. Reserves for reduction of labor capacity of hotel and restaurant product and their effective use in the enterprise personnel management system. Інфраструктура ринку. 2020. № 47. С. 123-128.

12. Tsviliy S., Gurova D., Zhuravlova S., Kuklina T. Creation of a legal hub by micro-enterprises in the field of tourism. Fundamental and applied research in the modern world: Abstracts of the 6th International scientific and practical conference. BoScience Publ., Jan. 20-22, 2021. Boston, USA. 2021. Pp. 255-263.

\section{References:}

1. Durovych A. P. (2003) Marketing v turizme [Marketing in tourism]. Minsk: Novoe znanie. (in Russian)

2. Fomyshyn S. V. (2002) Mezhdunarodnye ekonomicheskii otnosheniia na rubezhe tysiacheletiii [International economic relations at the turn of the millennium]. Kherson: Oldi-plus. (in Russian)

3. Korniienko O., Kuklina T. (2019) Mizhnarodnyi hotelnyi biznes: problemy ta perspektyvy [International hotel business: problems \& prospects]. Infrastruktura rynku (electronic journal), no. 31, pp. 27-30. Available at: http://www.market-infr.od.ua/journals/2019/31_2019_ukr/6.pdf (accessed 10 February 2021).

4. Kotler P. (2000) Marketing v tretem tysiacheleltii: kak sozdat, zavoevat i uderzhat rynok [Marketing in the third millennium: how to create, conquer and hold the market]. Moscow: «AST». (in Russian)

5. Kyfiak V. F. (2010) Stratehiia rozvytku terytorialnykh rekreatsiinykh system: teoriia, metodolohiia, praktyka [Strategy of development of territorial recreational systems: theory, methodology, practice]. Kyiv; Chernivtsi: Knyhy-XXI. (in Ukrainian)

6. Mochernyi S. V. (2006) Internatsionalizatsiia vyrobnytstva i suchasni tendentsii rozvytku svitovoho hospodarstva [Internationalization of production and modern trends in the world economy]. Ekonomika Ukrainy, no. 5, pp. 47-55.

7. Mykhailovska O. V. (2009) Vplyv hlobalizatsii informatsiinoho prostoru na rozvytok mizhnarodnykh innovatsiino-investytsiinykh protsesiv [Influence of globalization of information space on development of international innovation and investment processes]. Kyiv: Dakor: Skif. (in Ukrainian)

8. Strashynska L.V. (2011) Marketynh hotelnoho i restorannoho hospodarstva [Marketing of hotel and restaurant economy]. Kyiv: NUKHT. (in Ukrainian)

9. Tsviliy S., Gurova D., Bulatov S. (2020) Reserves for reduction of labor capacity of hotel and restaurant product and their effective use in the enterprise personnel management system. Infrastruktura rynku (electronic journal), no. 47, pp. 123-128. Available at: http://www.market-infr.od.ua/journals/2020/47_2020_ukr/25.pdf (accessed 10 February 2021).

10. Tsviliy S., Gurova D., Zhuravlova S., Kuklina T. (2021) Creation of a legal hub by micro-enterprises in the field of tourism. Proceedings of the Fundamental and applied research in the modern world (USA, Boston, January 20-22, 2021), Boston: BoScience Publisher, pp. 255-263.

11. Zaitseva V. M. (ed.) (2017) Industriia hostynnosti v Ukraini: stan i tendentsii rozvytku [Hospitality industry in Ukraine: state and trends]. Zaporizhzhia: Prosvita. (in Ukrainian)

12. Zaitseva V. M. (ed.) (2018) Stratehichne upravlinnia hotelnymy pidpryiemstvamy v umovakh hlobalizatsiii [Strategic management of hotel enterprises in the context of globalization]. Zaporizhzhia: ZNTU. (in Ukrainian)

\section{МАРКЕТИНГ ОТЕЧЕСТВЕННОГО ГОСТИНИЧНО-РЕСТОРАННОГО ПРЕДПРИЯТИЯ В МЕЖДУНАРОДНОМ ЦИФРОВОМ ПРОСТРАНСТВЕ}

Аннотация. В статье изучены теоретические подходы по развитию системы цифровых услуг. Обобщен мировой опыт по изучению методического аппарата в маркетинге сферы сервиса. Разработана модель комплексного гостинично-ресторанного продукта. Даны практические рекомендации по формированию стратегии цифрового маркетинга гостинично-ресторанных услуг. Предложена схема организационного построения отдела маркетинга компании в соответствии с требованиями цифровизации бизнеса. Выделены требования к маркетологу для налаживания рационального взаимодействия в цифровом международном пространстве фирм с потребителями. Определены приоритетные задачи отечественной гостинично-ресторанной компании при формировании у клиента мышления цифрового потребления. Сделан вывод о целесообразности дальнейших разведок по разработке механизма изучения цифровой лояльности покупателей гостинично-ресторанного продукта.

Ключевые слова: маркетинг, цифровое пространство, международный бизнес, гостинично-ресторанное предприятие, стратегия, потребитель. 


\section{МАРКЕТИНГ ВІТЧИЗНЯНОГО ГОТЕЛЬНО-РЕСТОРАННОГО ПІДПРИЄМСТВА В МІЖНАРОДНОМУ ЦИФРОВОМУ ПРОСТОРІ}

Анотація. В статті розглянуто теоретичні підходи щодо розвитку системи цифрових послуг, що формується в межах сучасної концепції цифрової сервісної економіки. Узагальнено міжнародний досвід з вивчення методичного інструментарію в площині маркетингу сфери сервісу, що дозволило зробити висновок відносно значної більшості типових моделей, які базуються на чіткому визначенні типу послуги, в залежності від якого виникає необхідність у відповідних маркетингових заходах з боку підприємства. Розроблено модель комплексного готельно-ресторанного продукту на основі обгрунтування стратегічного успіху компаній у боротьбі з конкурентами, який залежить від впровадження цифрового маркетингу, розуміння технологій якого дозволяє забезпечити інтернаціоналізацію готельно-ресторанного бізнесу і повноцінно увійти з власним продуктом в глобальний цифровий простір. Надано практичні рекомендації щодо формування та реалізації стратегії цифрового маркетингу відносно готельно-ресторанних послуг. Запропоновано схему організаційної побудови відділу маркетингу готельно-ресторанної компанії у відповідності до вимог цифровізації бізнесу, фундаментом якої є: створення відділу цифрових технологій фірми, до компетенції якого увійде робота по структуризації та впорядковуванню маркетингової інформації в синхронізовану цифрову систему; інтеграція системи 3 корпоративною інформаційною системою підприємства; організація відділу інтернет-маркетингу, до завдань якого повинні відноситися дієві заходи залучення додаткових клієнтів за допомогою інтернет-ресурсів. Виокремлено вимоги до маркетолога для налагодження раціональної взаємодії у цифровому міжнародному просторі компаній готельно-ресторанного бізнесу з покупцями та споживачами комплексного продукту. Визначено пріоритетні завдання вітчизняної готельно-ресторанного підприємства при формуванні у споживача мислення цифрового споживання. Зроблено висновок, що подальші розвідки у цьому напрямку є цікавими у площині розробки механізму вивчення цифрової лояльності покупців комплексного готельно-ресторанного продукту.

Ключові слова: маркетинг, цифровий простір, міжнародний бізнес, готельно-ресторанне підприємство, стратегія, споживач. 